\title{
Analisis Video Likes to Video Views Ratio Tiktok Pada Pada 5 Brand Skincare Lokal Terbaik \& Terlaris di Indonesia
}

\author{
Adik Putri Andini \\ STIMIK STIKOM Indonesia \\ Pa.putriandini@gmail.com
}

\begin{abstract}
ABSTRAK
TikTok is a social media application launched by a Chinese company. TikTok allows users to create 15 -second videos accompanied by music, filters, and several other creative features. It is used by 154 countries around the world with 800 million daily active users. In Indonesia alone, there are 30.7 million active users, making Indonesia the country with the largest TikTok users in the world. The large number of active TikTok users in Indonesia can certainly provide an opportunity for brands to make the TikTok platform a social media marketing platform. There are 5 skincare vendors in Indonesia that use TikTok as a marketing platform, namely: Somethinc Official, N'Pure Official, Avoskin Beauty, Whitelab Official, Ms.Glow Official. The purpose of this study is to calculate the credibility of the TikTok account performance in the Top 5 Best Local Skincare Brands in Indonesia. The method used for this research is quantitative exploratory method. The results of this study indicate that the local skincare brand Whitelab Official gets the first rank and has good account performance credibility.
\end{abstract}

\begin{abstract}
ABSTRAK
TikTok merupakan aplikasi sosial media yang diluncurkan oleh perusahaan asal Tiongkok. TikTok memungkinkan penggunanya membuat video berdurasi 15 detik yang disertai dengan musik, filter, dan beberapa fitur kreatif lainnya. Telah digunakan oleh 154 negara diseluruh dunia dengan 800 juta pengguna aktif setiap harinya. Di Indonesia sendiri terdapat 30,7 juta pengguna yang aktif sehingga menjadikan Indonesia sebagai negara dengan pengguna TikTok terbesar di dunia. Maraknya jumlah pengguna TikTok yang aktif di Indonesia tentu dapat memberikan peluang bagi brand untuk menjadikan platform TikTok sebagai platform social media marketing. Adapun 5 vendor skincare di Indonesia yang memanfaatkan TikTok sebagai platform marketing, yaitu : Somethinc Official, N'Pure Official, Avoskin Beauty, Whitelab Official, Ms.Glow Official. Tujuan dari penelitian ini yaitu untuk menghitung kredibilitas dari performa akun TikTok Top 5 Brand Skincare Lokal Terbaik di Indonesia. Metode yang digunakan untuk penelitian ini yaitu metode eksploratif kuantitatif. Hasil dari penelitian ini menunjukan bahwa brand skincare local Whitelab Official mendapatkan peringkat pertama dan memiliki kredibilitas performa akun yang baik.
\end{abstract}

\section{PENDAHULUAN}

Teknologi informasi dan komunikasi yang telah berkembang dengan pesat mampu memudahkan aktivitas manusia dalam cara berkomunikasi. Media sosial memberikan pengaruh yang cukup besar, saat ini media sosial diajadikan sebagai sarana berkomunikasi dalam setiap aktifitas keseharian bersosial di masyarakat, menjalin silaturahmi sesama teman kita dimana saja tanpa harus bertatap muka. Mendapatkan banyak temen dari mana saja dan 
terkadang dengan jejaring social. Komunikasi tidak hanya dapat dilakukan secara fisik, tetapi juga dapat dilakukan dengan menggunakan berbagai aplikasi media sosial di dunia maya. Karena berbagai ragamnya aplikasi social media, komunikasi menjadi lebih menyenangkan dengan fitur masing-masing dari social media.

Pesatnya perkembangan teknologi social media dari yang awalnya hanya sekedar email dan chatting, saat ini sudah banyak ragam social media yang dapat digunakan sebagai alat komunikasi. Salah satu social media yang trending saat ini yaitu Tiktok. Tiktok adalah social media yang menggunakan video sebagai media utama. Yang memungkinkan user saling berkomunikasi dengan video ataupun hanya sekedar membuat konten edukasi ataupun hiburan.

Aplikasi TikTok berasal dari negeri Tiongkok yang diluncurkan pada awal September tahun 2016 oleh seorang pengusaha bernama Zhang Yiming yang sekaligus pendiri dari sebuah perusahaan berbasis teknologi yaitu ByteDance. Sebelum dikenal luas oleh masyarakat dunia, aplikasi ini dulunya dikenal dengan sebutan Douyin di negara asalnya. Dimana pengguna hanya menggunakan aplikasi ini untuk membagikan video pendek dengan durasi 15 detik ke pada seluruh pengguna lainnya.

Siapa sangka, aplikasi ini ternyata mendapat respon positif dari penggunanya, sehingga aplikasi ini menjadi salah satu aplikasi yang cukup populer di negara asalnya. Karena merasa berhasil memperkenalkan di negara asalnya sendiri, BytdeDance akhirnya mencoba untuk memperkenalkan aplikasi ini kepada masyarakat Dunia. Sehingga ByteDance memutuskan untuk mengganti nama Douyin menjadi Tik Tok.

Di Indonesia terdapat 30,7 juta pengguna Tiktok yang aktif di Indonesia menjadikan negara Indonesia sebagai negara dengan pengguna TikTok terbesar di dunia. Dengan banyaknya jumlah pengguna Tiktok yang aktif di Indonesia tentu memberikan peluang bagi brand untuk menjadikan Tiktok sebagai platform social media marketing. Cukup banyak akun perusahaanperusahaan terkenal yang ada pada tiktok, contohnya pada vendor kecantikan diantaranya yaitu : Somethinc Official, N'Pure Official, Avoskin Beauty, Whitelab Official, Ms.Glow Official.

Penelitian ini menggunakan metode eksploratif kuantitatif, dan akan menghitung menggunakan rasio-rasio yang ada pada TikTok. Pada penelitian (Permana and Meinarni 2021) menjelaskan bahwa terdapat 17 rasio yang ada pada sosial media TikTok dan relevan digunakan sebagai media ukur kredibilitas akun yang ada. Penelitian ini hanya berfokus untuk menghitung kredibilitas Video Likes to Video Views Ratio pada Top 5 Vendor Kecantikan di Indonesia. Tujuan dari penelitian ini adalah mengetahui kredibilitas performa dari akun TikTok Top 5 Vendor Kecantikan di Indonesia menggunakan Video Likes to Video Views Ratio.

\section{TINJAUAN PUSTAKA}

Perkembangan bidang teknologi saat ini terjadi begitu cepat. Teknologi seperti kebutuhan yang tidak dapat dijauhkan dari masyarakat. Manfaat teknologi informasi tidak hanya untuk meningkatkan kegiatan operasional kerja saja, tetapi juga memberikan keuntungan dan nilai tambah bagi perusahaan atau lembaga tersebut.(Siaha Widodo 2019) Berbagai macam kemudahan Berdasarkan hasil studi Polling Indonesia yang bekerjasama dengan Asosiasi Penyelengara Jasa Internet Indonesia (APJII) mendapatkan bahwa sebanyak 171,17 juta jiwa atau bila dipresentasekan sekitar $64,8 \%$ penduduk Indonesia merupakan pengguna Internet. Angka yang sangat besar ini tentunya membuat masyarakat Indonesia mengalami perubahan budaya dalam bermedia saat ini, karena tentunya terdapat peralatan dan prosedur baru yang akan diadaptasi oleh masyarakat itu sendiri dalam penggunaannya. 
Di tahun 2020, sosial media di Indonesia yang mengalami perkembangan pesat hingga menjadi budaya populer adalah aplikasi Tiktok. Tik Tok adalah aplikasi yang memberikan special effects unik dan menarik yang dapat digunakan oleh penggunanya dengan mudah sehingga dapat membuat video pendek dengan hasil yang keren serta dapat dipamerkan kepada teman atau pengguna lainnya. Aplikasi sosial video pendek ini memiliki dukungan musik yang banyak sehingga penggunanya dapat melakukan performanya dengan tarian, gaya bebas, dan masih banyak lagi sehingga mendorong kreativitas penggunanya menjadi content creatore ataupun media promosi. Seiring perkembangan teknologi yang berkembang pesat dengan adanya internet memunculkan berbagai aplikasi di media sosial yang memberikan peluang sebuah usaha. Saat ini sudah banyak usaha yang menggunakan media sosial untuk mempromosikan produk dan menjadikannya sebagai strategi bisnis. Strategi marketing yang dapat dilakukan dengan platform Tik Tok antara lain dengan menggunakan hashtag, hashtag adalah sebuah tanda yang memiliki maksud agar suatu pokok bahasan, peristiwa, bahkan sebuah produk dapat mudah ditemukan. Dengan hashtag yang diberikan dapat digunakan membantu konsumen mencari produk yang dicarinya atau dibutuhkannya. Mmengikuti trend yang terjadi strategi pemasaran dengan menggunakan Tik Tok mengandalkan video yang menggambarkan hal yang sedang trending. Untuk kondisi ini produsen harus dapat menemukan moment yang sesuai untuk produknya untuk dapat dipromosikan dan dikenalkan ke konsumen. Melakukan kolaborasi dengan para influence dengan influencer yang sedang digemari dan memiliki banyak pengikut sehingga strategi promosi yang dilakukan lewat Tik Tok dapat memikat dan menarik banyak orang, memberikan deskripsi yang jelas agar seseorang akan tertarik pada sebuah video selain dari konten yang bagus juga terdapat deskripsi/info produk yang disampaikan jelas.

Strategi ini dilakukan dengan melakukan upload/posting video secara rutin sehingga lebih banyak orang yang akan melihat atau mengunjungi akun produk yang akan dijual. Semakin banyak video yang diunggah maka membuka peluang konsumen untuk menonton dan jika sudah semakin banyak konten anda dilihat maka strategi yang lain adalah dapat diberikan iklan sehinggan promosi yang di tawarkan dapat dilakukan dan dapat ditargetkan.

Banyaknya pengguna smartphone menjadi peluang bagi para produsen untuk menggunakannya sebagai sarana promosi produk. Digital marketing salah satunya, perkembangan teknologi dan media informasi berdampak terhadap promosi yang dilakukan. Dimana sudah beralih ke promosi online, banyak pengusaha yang lebih memilih mempromosikan produk mereka

Dengan internet salah satunya dengan media sosial. Dengan keuntungan lebih murah, proses promosi cepat, jangkauannya luas dan dapat dilihat oleh seluruh dunia. Namun kekurangan promosi dengan penggunaan media internet yaitu dibutuhkan sebagai kreativitas yang tinggi untuk dapat mempromosikan produknya karena banyaknya para pesaing / competitor. TikTok dirasakan memiliki kekuatan ataupun pengaruh dalam industri, sehingga menimbulkan kualitas akun yang menentukan strata maupun kredibilitas pemilik akun. Kredibilitas akun TikTok merupakan suatu hal yang cukup penting untuk berbagai kepentingan. Kredibilitas sebuah akun TikTok dapat diukur dari tingkat performa yang dihasilkan secara matematis. Dalam mengukur performa diperlukan skala pengukuran yang tertuang ke dalam rasio. 


\section{METODE PENELITIAN}

Penelitian ini menggunakan metode eksploratif kuantitatif untuk mengetahui kredibilitas dari performa akun TikTok 5 Brand Skincare Lokal Terbaik dan Terlaris di Indonesia Penelitian Eksploratif merupakan studi dengan melakukan penelusuran, terutama dalam pemantapan konsep yang akan digunakan dalam ruang lingkup yang penelitian yang lebih luas dengan jangakauan konseptual yang lebih besar (Yusuf, 2017). Dalam melakukan eksplorasi, konsep yang matang menjadi goal dalam penelitian dan jangakauan konseptual yang lebih luas. Penelitian eksploratif merupakan penelitian awal yang bertujuan untuk mendapatkan gambaran mengenai suatu topik penelitian yang akan diteliti lebih jauh (Morissan, 2017).

Tujuan dari penelitian ini yaitu mengetahui nilai kredibillitas dari performa akun TikTok 5 Brand Skincare Lokal Terbaik dan Terlaris di Indonesia. Ada beberapa langkah yang harus dilakukan dalam penelitian ini, sehingga mampu menemukan peringkat pertama akun TikTok Brand Skincare Lokal Terbaik dan Terlaris di Indonesia yang memiliki performa terbaik. Langkah-langkah yang dilakukan pada penelitian ini, diantaranya yaitu :

\section{Melakukan Eksplorasi Pada Website Untuk Menentukan Objek yang Akan Dianalisa.}

Eksplorasi ini dilakukan pada beberapa halaman website yang menyediakan informasi mengenai objek yang akan di teliti. Setelah ekslorasi selesai dilakukan, sehingga ditemukan nama-nama vendor skincare lokal di Indonesia yang akan dijadikan objek analisa. Setelah melakukan eksplorasi pada halaman website, maka langkah selanjutnya yaitu mencari nama akun TikTok dari masing-masing vendor smartphone. Dengan memastikan semua vendor memiliki akun pada aplikasi sosial media TikTok.

\section{Menghitung Nilai Rata-Rata Variable Dari Top 5 Brand Skincare di Indonesia.}

Pada langkah ini, peneliti menghitung nilai variable video likes dan variable video views. Variabel merupakan segala sesuatu yang berbentuk apa saja yang di tetapkan oleh peneliti untuk di pelajari sehingga di peroleh informasi tentang hal tersebut, kemudian di tarik kesimpulannya (Sugiyono, 2017) Untuk menghitung nilai rata-rata dari variabel video likes dan variabel video views yaitu dengan cara mengambil minimal 10 postingan kemudian di hitung sehingga menemukan nilai rata-rata dari masing-masing variabel. 


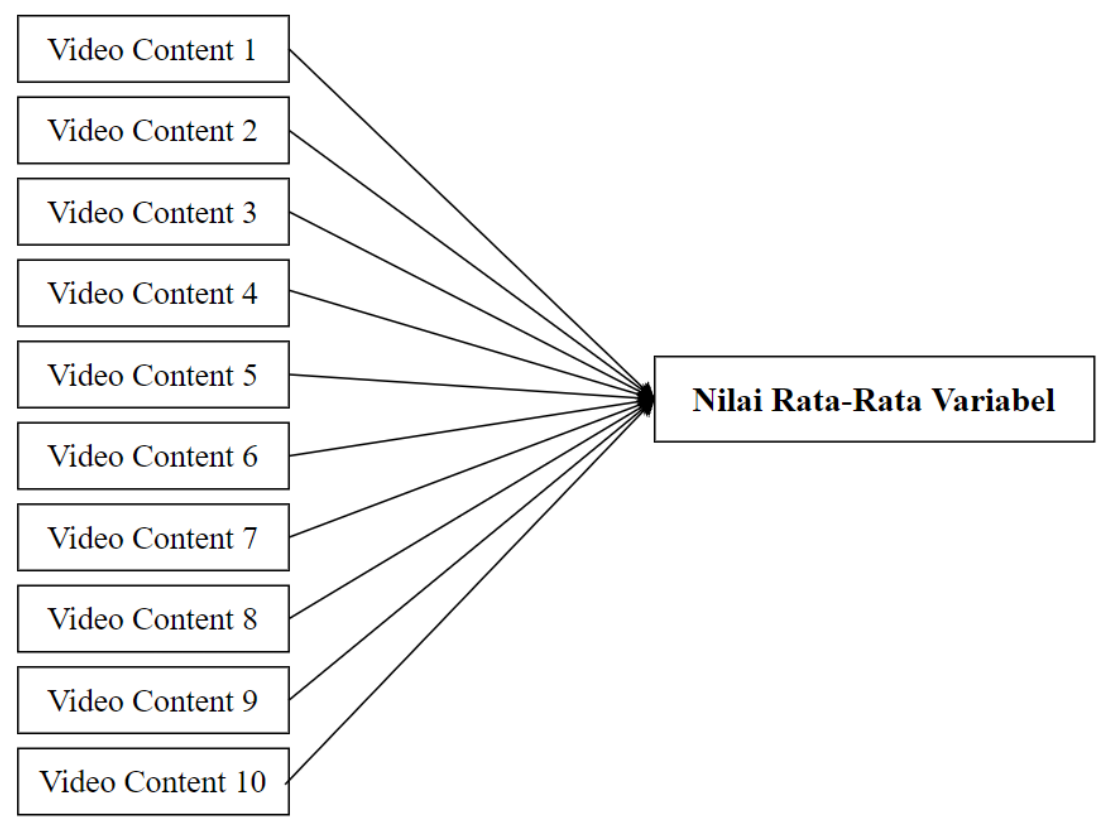

Gambar 1. Analisa Nilai Rata-Rata Variabel.

\section{Menghitung Nilai Kredibilitas Rasio}

Untuk menghitung nilai kredibilitas dari video likes to video views ratio, peneliti menggunakan cara membagi nilai variabel pertama dengan nilai variabel kedua. Jika video likes memiliki nilai 100 dan video views memiliki nilai 300, maka cara menghitungnya yaitu $100: 300=0,3$. Dengan begitu nilai dari video likes to video views ratio adalah 0,3 .

\section{Menentukan Peringkat Pada Akun TikTok}

Pada langkah terakhir yang dilakukan pada penelitian ini yaitu menentukan peringkat pada masing-masing rasio yang ada. Pada penentuan peringkat perlu melihat karakteristik dari rasio yang di teliti. Jika karakteristik rasio merupakan kategori rendah, maka objek yang memiliki nilai terendah akan mendapatkan angka 5 dan objek yang memiliki nilai tertinggi akan mendapatkan angka 1. Namun jika rasio memiliki karakteritik tinggi maka objek yang mendapatkan nilai tinggi akan mendapatkan angka 5 dan objek yang mendapatkan nilai terendah akan mendapatkan angka 1. Setelah mendapatkan hasil kredibilitas ratio maka dapat disimpulkan objek yang mana mendapatkan peringkat 1 sampai dengan peringkat 5 . 


\section{HASIL DAN PEMBAHASAN}

Akun TikTok dari 5 Brand Skincare Lokal Terbaik dan Terlaris di Indonesia, diantaranya :

\section{Somethinc Official}

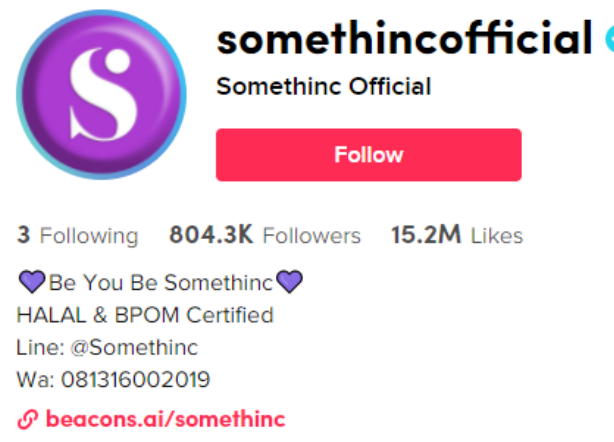

Gambar 1. Akun TikTok Somethinc Official

Sumber : https://www.tiktok.com/@ Somethincofficial (akses pada 20-10-2021)

\section{N'Pure Official}

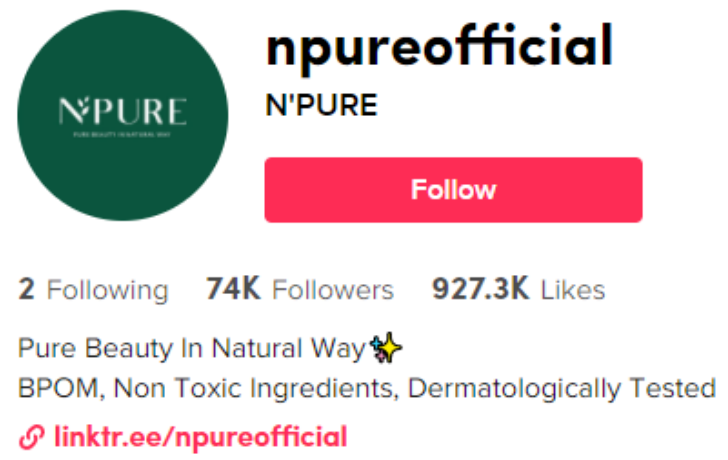

Gambar 2. Akun TikTok N'Pure Official

Sumber : https://www.tiktok.com/@npureofficial (akses pada 20-10-2021) 


\title{
3. Avoskin Beauty
}

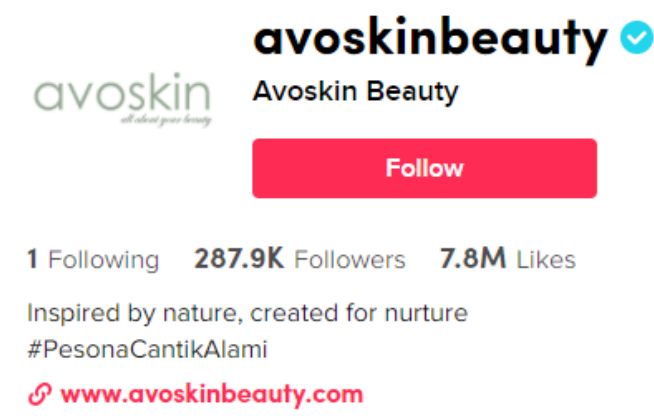

Gambar 3. Akun TikTok Avoskin Beauty

Sumber : https://www.tiktok.com/@avoskinbeauty (akses pada 20-10-2021)

\section{Whitelab Official}

\author{
whitelabid \\ whitelab \\ Whitelab Official \\ Follow \\ 1 Following 83.5K Followers 929.8K Likes \\ Not Your Ordinary Skincare \\ Powered by Science, Inspired by Beauty \\ $\odot$ www.whitelab.co.id \\ Gambar 4. Akun Tiktok Whitelab_id
}

Sumber : https://www.tiktok.com/@whitelabid (akses pada 20-10-2021

\section{Ms. Glow Official}

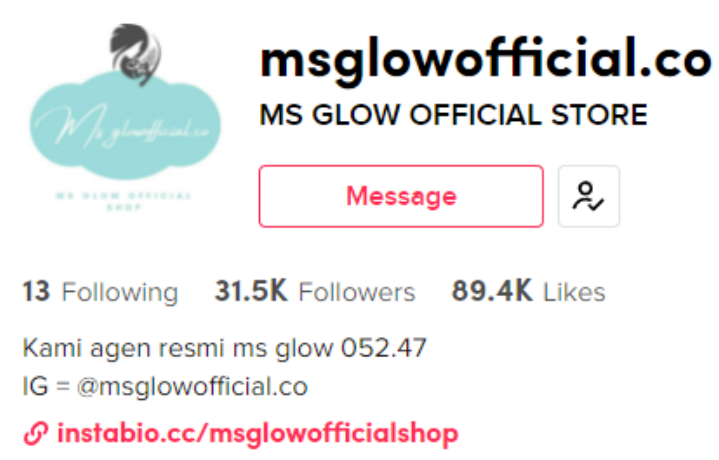

Gambar 5. Akun TikTok Ms. Glow Official

Sumber : https://www.tiktok.com/@msglowofficial.co (akses pada 20-10-2021) 
Dari kelima akun TikTok 5 Brand Skincare Lokal Terbaik dan Terlaris di Indonesia, peneliti menemukan nilai dari masing-masing variabel yang ada untuk menghitung rasio Video Comments to Video Views dari setiap akun. Pada akun TikTok terdapat 7 variabel, diantaranya yaitu :

1. Likes

2. Followers

3. Following

4. Video Likes

5. Video Comments

6. Video Share

7. Video Views

Dari ketujuh variabel tersebut peneliti hanya fokus untuk menemukan hasil dari 2 variabel, yaitu :

1. Video Likes

2. Video Views

Dari kedua variabel tersebut kemudian dianalisa sehingga menemukan nilai rata-rata dari variabel video likes dan variabel video views. Untuk menghitung nilai rata-rata dari variabel video likes dan variabel video views yaitu dengan cara mengambil minimal 10 postingan kemudian di hitung sehingga menemukan nilai rata-rata dari masing-masing variabel. Berikut merupakan tabel nilai rata-rata dari masing-masing skincare lokal terbaik di Indonesia, yaitu :

Tabel 1. Analisa Nilai Rata-Rata Nilai Variabel Video Likes dan Video Views

Akun TikTok Somethinc Official

\begin{tabular}{|c|c|c|}
\hline No & $\begin{array}{l}\text { Video } \\
\text { Likes }\end{array}$ & $\begin{array}{l}\text { Video } \\
\text { Views }\end{array}$ \\
\hline 1 & 6,181 & 150,609 \\
\hline 2 & 7,048 & 196,206 \\
\hline 3 & 10,201 & 188,654 \\
\hline 4 & 1,720 & 22,657 \\
\hline 5 & 857 & 11,302 \\
\hline 6 & 408 & 7,939 \\
\hline 7 & 1,026 & 18,390 \\
\hline 8 & 127 & 5,061 \\
\hline 9 & 444 & 10,865 \\
\hline 10 & 1,498 & 64,201 \\
\hline Total & 2,951 & 67,588 \\
\hline
\end{tabular}


Tabel 2. Analisa Nilai Rata-Rata Nilai Variabel Video Likes dan Video Views Akun TikTok TikTok N'Pure Official

\begin{tabular}{|c|c|c|}
\hline No & $\begin{array}{c}\text { Video } \\
\text { Likes }\end{array}$ & $\begin{array}{c}\text { Video } \\
\text { Views }\end{array}$ \\
\hline 1 & 30,756 & $2,200,956$ \\
\hline 2 & 17,859 & $1,006,178$ \\
\hline 3 & 6,573 & 344,566 \\
\hline 4 & 14 & 136 \\
\hline 5 & 26 & 311 \\
\hline 6 & 64 & 889 \\
\hline 7 & 415 & 10,500 \\
\hline 8 & 87 & 1,758 \\
\hline 9 & 325 & 23,601 \\
\hline 10 & 607 & 9,367 \\
\hline Total & $\mathbf{5 , 6 7 3}$ & $\mathbf{3 5 9 , 8 2 6}$ \\
\hline \multicolumn{3}{|c|}{ Sumber Pengolah Data Excel }
\end{tabular}

Tabel 3. Analisa Nilai Rata-Rata Nilai Variabel Video Likes dan Video Views Akun TikTok Avoskin Beauty

\begin{tabular}{|c|c|c|}
\hline No & $\begin{array}{c}\text { Video } \\
\text { Likes }\end{array}$ & $\begin{array}{c}\text { Video } \\
\text { Views }\end{array}$ \\
\hline 1 & 30 & 635 \\
\hline 2 & 35 & 644 \\
\hline 3 & 83 & 2,084 \\
\hline 4 & 176,600 & $11,600,567$ \\
\hline 5 & 199,701 & $16,400,276$ \\
\hline 6 & 2,447 & 30,355 \\
\hline 7 & 155 & 4,306 \\
\hline 8 & 40,303 & $5,880,012$ \\
\hline 9 & 123 & 3,944 \\
\hline 10 & 388 & 12,107 \\
\hline Total & $\mathbf{4 1 . 9 8 7}$ & $\mathbf{3 , 3 9 3 , 4 9 3}$ \\
\hline \multicolumn{3}{|c|}{ Sumber : Pengolah Data Excel }
\end{tabular}


Tabel 4. Analisa Nilai Rata-Rata Nilai Variabel Video Likes dan Video Views Akun TikTok Whitelab Indonesia

\begin{tabular}{|c|c|c|}
\hline No & $\begin{array}{c}\text { Video } \\
\text { Likes }\end{array}$ & $\begin{array}{c}\text { Video } \\
\text { Views }\end{array}$ \\
\hline 1 & 23 & 320 \\
\hline 2 & 37 & 710 \\
\hline 3 & 63 & 1,259 \\
\hline 4 & 71 & 1,467 \\
\hline 5 & 69 & 1,618 \\
\hline 6 & 154 & 3,021 \\
\hline 7 & 128 & 8,721 \\
\hline 8 & 43,209 & 578,007 \\
\hline 9 & 556 & 16,500 \\
\hline 10 & 164 & 5,279 \\
\hline Total & $\mathbf{4 , 4 4 7}$ & $\mathbf{6 1 , 6 9 0}$ \\
\hline \multicolumn{3}{|c|}{ Sumber : Pengolah Data Excel }
\end{tabular}

Tabel 5. Analisa Nilai Rata-Rata Nilai Variabel Video Likes dan Video Views TikTok Ms. Glow

\begin{tabular}{|c|c|c|}
\hline No & $\begin{array}{c}\text { Video } \\
\text { Likes }\end{array}$ & $\begin{array}{c}\text { Video } \\
\text { Views }\end{array}$ \\
\hline 1 & 5 & 241 \\
\hline 2 & 3 & 201 \\
\hline 3 & 3 & 151 \\
\hline 4 & 28 & 1,486 \\
\hline 5 & 28 & 1,897 \\
\hline 6 & 12 & 1,215 \\
\hline 7 & 183 & 19,308 \\
\hline 8 & 227 & 18,302 \\
\hline 9 & 200 & 15,204 \\
\hline 10 & 131 & 11,300 \\
\hline Total & $\mathbf{8 2}$ & $\mathbf{6 , 9 3 1}$ \\
\hline
\end{tabular}

Sumber : Pengolah Data Excel 
Setelah menghitung nilai rata-rata tersebut, maka akan menemukan hasil akhir nilai rata-rata dari variabel video likes dan

Tabel 6. Nilai Variabel Pada Akun TikTok 5 Brand Skincare Lokal Terbaik dan Terlaris di Indonesia

\begin{tabular}{|l|c|c|c|c|c|}
\hline Variable & Somethinc & N'Pure & $\begin{array}{c}\text { Avoskin } \\
\text { Beauty }\end{array}$ & Whitelab & Ms. Glow \\
\hline Video Likes & 2951 & 5673 & 41987 & 4447 & 82 \\
\hline Video Views & 67588 & 359826 & 3393493 & 61690 & 6931 \\
\hline
\end{tabular}

Sumber : Pengolah Data Excel

Pada akun TikTok terdapat 17 rasio yang relevan digunakan untuk mengukur kredibilitas pada masing-masing akun. Namun pada penelitian kali ini hanya berfokus untuk menghitung Video Likes to Video Views Ratio. Untuk menghitung kredibilitas dari masing-masing akun TikTok setiap brand skincare, peneliti menghitung dengan cara : variabel 1 akan dibagi dengan variabel 2, sehingga ditemukan hasil analisisa dari rasio tersebut.

Tabel 7. Hasil Perhitungan Rasio Akun TikTok

\begin{tabular}{|l|l|l|l|l|l|l|}
\hline NO & RATIO & Somethinc & N'Pure & $\begin{array}{l}\text { Avoskin } \\
\text { Beauty }\end{array}$ & Whitelab & Ms. Glow \\
\hline 1 & $\begin{array}{l}\text { Video Likes to } \\
\text { Video Views Ratio }\end{array}$ & 0.04366134 & 0.01576483 & 0.01237265 & 0.07209249 & 0.01183176 \\
\hline
\end{tabular}

Sumber : Pengolah Data Excel

Video Likes to Video Views Ratio memiliki karakteristik yang tinggi, artinya semakin tinggi nilai yang dihasilkan maka semakin baik kredibilitas dari performa akun tersebut. Untuk memberikan peringkat pada masing-masing Brand Skincare, peneliti memberikan angka 5 kepada brand yang mendapatkan nilai tertinggi dan angka 1 untuk brand skincare yang mendapatkan nilai terendah. Berikut merupakan tabel urutan nilai yang dihasilkan oleh masingmasing vendor smartphone.

Tabel 8. Nilai Rasio Akun TikTok 5 Brand Skincare Lokal Terbaik dan Terlaris di Indonesia

\begin{tabular}{|c|c|c|c|c|c|}
\hline \multirow{2}{*}{ RATIO } & \multicolumn{5}{|c|}{ NILAI } \\
\cline { 2 - 6 } & Somethinc & N'Pure & $\begin{array}{l}\text { Avoskin } \\
\text { Beauty }\end{array}$ & Whitelab & Ms. Glow \\
\hline $\begin{array}{l}\text { Video Likes to Video } \\
\text { Views Ratio }\end{array}$ & 2 & 4 & 3 & 1 & 5 \\
\hline
\end{tabular}

Sumber : Pengolah Data Excel 
Dari Tabel Nilai Rasio Akun TikTok Top 5 Brand Skincare Lokal Terbaik dan Terlaris di Indonesia dapat simpulkan bahwa Whitelab mendapatkan nilai tertinggi untuk rasio Video Likes to Video Views. Sedangkan akun TikTok Ms. Glow mendapatkan nilai terendah untuk rasio ini. Jadi, pada penelitian ini Whitelab memiliki kredibilitas performa yang lebih baik dibandingkan dengan brand yang lainnya.

\section{KESIMPULAN}

Tujuan dari penelitian ini adalah mengetahui kredibilitas performa dari akun TikTok Top 5 Brand Skincare Lokal Terbaik dan Terlaris di Indonesia menggunakan Video Likes to Video Views Ratio. Top 5 Brand Skincare Lokal tersebut diantaranya : Somethinc Official, Npure Official, Avoskin Beauty, Whitelab Official dan Ms. Glow. Dari kelima brand skincare tersebut dapat disimpulkan bahwa :

1. Peringkat pertama diraih oleh brand Whitelab Official dengan nilai tertinggi yaitu 0.07209249

2. Peringkat kedua diraih oleh brand Somethinc Official dengan nilai 0.04366134

3. Peringkat ketiga diraih oleh brand Avoskin Beauty dengan nilai 0.01237265

4. Peringkat keempat diraih oleh brand Npure dengan nilai 0.01576483

5. Peringkat kelima diraih oleh brand Ms Glow dengan nilai terendah yaitu 0.01183176 


\section{DAFTAR PUSTAKA}

Permana, I Putu Hendika, and Ni Putu Suci Meinarni. 2021. "Ratio Analysis on Tiktok (Social Media) for Qualitative Research Using Explorative Methods." Jurnal Ekonomi \& Bisnis JAGADITHA 8 (1): 30-38. https://doi.org/10.22225/JJ.8.1.2944.30-38.

Bulele Yohana Noni and Toni Wibowo. 2020. "Analisis Fenomena Sosial Media dan Kaum Milenial Studi Kasus Tiktok.” Jurnal Universitas Internasional Batam (1): 01-08. https://journal.uib.ac.id/index.php/cbssit/article/view/1463.

PRIANBODO, BAGUS. 2018. "PENGARUH 'TIKTOK' TERHADAP KREATIVITAS REMAJA SURABAYA,” December.

Mumtaz Syafika Zayyan and Saino.2021 "Pengaruh Penggunaan Tiktok Sebagai Media Promosi dan Trend Glow Up Terhadap Minat Beli Produk Kecantikan.” Jurnal Ekonomi dan Bisnis Universitas Negri, Surabaya. (1):01-10. https://journal.feb.unmul.ac.id/index.php/JURNALMANAJEMEN/article/view/9716

“Top 5 Brand Skincare Lokal Indonesia Terlaris Q1-2021 - Selular.ID.” n.d. Accessed October 11, 2021. https://sumsel.tribunnews.com/2021/07/01/5-brand-skincare-lokalindonesia-terlaris-tahun-2021-terbaik-yang-wajib-kalian-coba-bersama-teman?page=3

“Sejarah dan Fakta Tentang Aplikasi Tiktok - Selular.ID.” n.d. Accessed October 20, 2021. https://www.tagar.id/sejarah-dan-fakta-tentang-aplikasi-tiktok 